\title{
OBSERVATIONS ON LUMINESCENCE IN NOCTILUCA
}

\author{
By J. A. C. Nicol \\ The Plymouth Laboratory \\ (Text-figs. I-9)
}

Noctiluca miliaris Suriray is a well-known luminescent organism, and its light emission has been studied repeatedly. Hitherto, however, no attempt has been made to record the luminescent flashes of this species, either under normal conditions, or after experimental treatment. With the sensitive photoelectric recording methods now available it has become possible to subject the luminescent flashes of Noctiluca to experimental analysis, and with this end in view the present study of Noctiluca was undertaken.

Noctiluca is a dinoflagellate approximately spherical in shape and $0.2-$ $\mathrm{I} \cdot \mathbf{2} \mathrm{mm}$ in diameter. It possesses a single stout tentacle and a small flagellum by which it executes a limited amount of slow movement. The specific gravity of Noctiluca is less than that of sea water so that it tends to float at the surface. The explanation of this low density is still uncertain (Davis, I953). The interior of the cell is highly vacuolated and contains fine cytoplasmic strands which radiate outwards from the region of the nucleus to the periplast. E. N. Harvey (1952) has reviewed previous literature dealing with the luminescence of Noctiluca.

\section{MATERIAL AND METHODS}

During July and August 1955 there were large numbers of Noctiluca in the surface plankton off Plymouth, and abundant material became available for studies of luminescence. Dr M. W. Parke was successful in culturing Noctiluca in Erdschreiber solution. These cultures were supplied with Isochrysis galbana for food, and were subcultured at intervals. From them Noctiluca cells were removed for study when required. Further supplies of Noctiluca were obtained in June 1957 , in the Bay of Douarneney ( $48^{\circ} \mathrm{I} 8.5^{\prime} \mathrm{N} ., 5^{\circ} \mathrm{I} 3^{\prime} \mathrm{W}$.) and the Bay of Concarneau ( $47^{\circ} 5 \mathrm{I}^{\prime}$ N., $3^{\circ} 58^{\prime}$ W.) (R.V. 'Sarsia' cruise 3 of 1957).

The luminescent flashes of Noctiluca were detected by means of a photomultiplier tube. The photocurrent was passed through a $500 \mathrm{k} \Omega$ resistor, and voltage changes were amplified (DC amplifier) and recorded by means of cathode-ray oscilloscope and camera. The photomultiplier was an E.M.I. type no. 6685 , with an end-window $9 \mathrm{~mm}$ in diameter. This photomultiplier 
has I4 stages and was operated at voltages up to I80o V. The Sb-Cs cathode possesses maximal sensitivity in the violet and blue; the relative spectral sensitivity curve, as determined by the National Physical Laboratory, is shown elsewhere (Nicol, I958a, p. 34, fig. 2, curve A). The specimens of Noctiluca were placed in a small container closely underneath the end-window of the photomultiplier and all leads were screened to eliminate a.c. interference. For the majority of records, vertical deflexions of the oscilloscope spots were photographed on moving paper; a few photographs on film were also made of single and repeat sweeps of the oscilloscope when triggered by the stimulator.

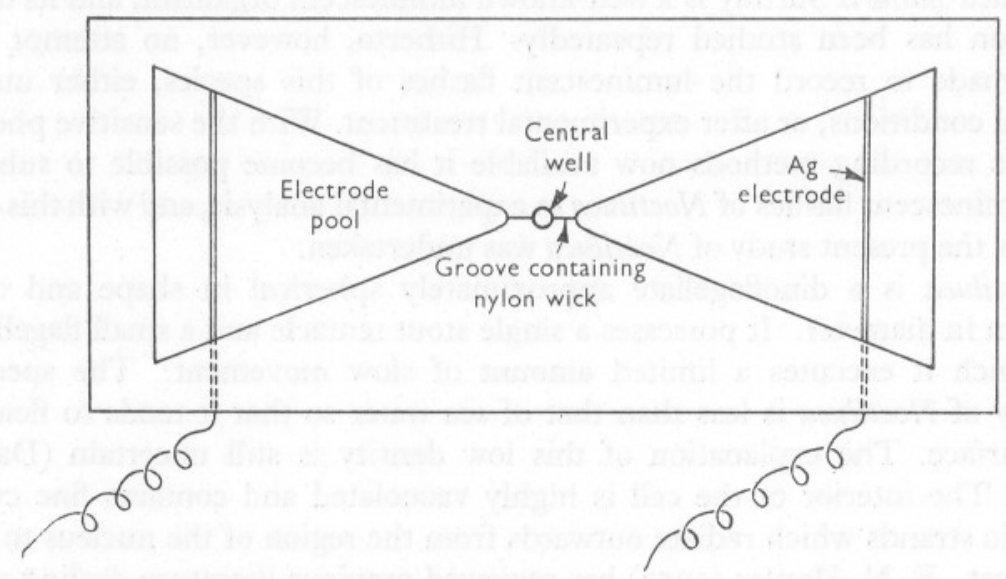

Fig. I. Diagram of the chamber used for electrical stimulation of Noctiluca. Modified from Chang (I954).

For electrical stimulation Noctiluca was placed in a Perspex chamber, provided with two silver electrodes and shaped as in Fig. I. The Noctiluca cell lay in the small central well, which was connected with two large lateral wells by narrow slits; the latter were filled with wet threads or agar. The whole chamber was flooded with sea water and was covered with a glass or perspex plate to prevent evaporation. Electrical stimuli consisted of condenser-discharges or square waves from electronic apparatus. Electrical stimuli were signalled on the second beam of the oscilloscope. A time signal was provided by the periodic flashing of a small lamp, controlled by a Palmer relay (this set-up was used with moving paper); or by an A.F. oscillator (used with sweeps and stationary film). Room temperatures at which the experiments were carried out varied from $18^{\circ}$ to $19^{\circ} \mathrm{C}$ (shore laboratory) and $20^{\circ}$ to $23^{\circ} \mathrm{C}$ (ship's laboratory). 


\section{OBSERVATIONS \\ MECHANICAL STIMULATION}

The natural stimulus evoking luminescence in Noctiluca is mechanical. Placed in a vessel, Noctilucae assemble at the top, especially about the margin of the vessel. Upon agitating the container, many of the cells respond by a bright flash. Similarly, moving an object through the water, or blowing a jet of air on the surface, agitates the cells and causes them to flash. Animals moving through the water also disturb the Noctilucae, and make them luminesce. In a breffit containing a large number of Noctilucae and some Calanus it was observed that whenever a Calanus invaded the superficial Noctiluca layer, it gave rise to a bright glow in a circumscribed area, owing to agitation of a group of Noctiluca cells.

When a single cell is mechanically stimulated by agitating the container in which it lies, it is found that the intensity of the flash depends on the vigour of stimulation, a slight shake giving a faint flash, a brisk shake a stronger flash (Fig. $2 a, b$ ). At a temperature of $17^{\circ} \mathrm{C}$ the flash duration varied from 22 to $95 \mathrm{msec}$ (a bright flash possessing a longer duration). The flash of a single cell, lasting $95 \mathrm{msec}$, had the following temporal characteristics: time to maximum, $20 \mathrm{msec}$; time to half maximum, Io $\mathrm{msec}$; decay time from maximum, $70 \mathrm{msec}$; time of half decay, $20 \mathrm{msec}$.

These figures for response characteristics are presented to give some idea of the magnitudes involved. With present recording technique they make no claim to absolute accuracy, since they depend on the amplification characteristics of the apparatus. At high amplification, threshold for measurable deflexion of the oscilloscope beam is lowered, and the response appears to start sooner, and last longer, than at low amplifications. The apparent duration of a flash, therefore, depends on the amplification-factor. (This effect has been analysed in the responses of cells stimulated electrically, and is discussed on p. 54I.)

Various methods were tried to obtain more accurate regulation of mechanical stimulation than could be achieved merely by manual operation. This proved difficult because the Noctiluca is buffered by the pool of sea water in which it floats and because, when disturbed, it sinks and changes position. Some records were obtained by stimulating Noctilucae mechanically by means of a loud speaker. Condenser shocks, fed into the speaker, shook the dish and caused the Noctilucae to flash.

From a group of about ro cells the following response parameters were determined for a flash lasting $\mathrm{I} 20 \mathrm{msec}\left(17^{\circ} \mathrm{C}\right)$. Rise to maximum occupied $43 \mathrm{msec}$; half maximum, $30 \mathrm{msec}$; decay from maximum occupied $80 \mathrm{msec}$; half decay, $20 \mathrm{msec}$. Latency from time of condenser-discharge varied from Io to $30 \mathrm{msec}$.

Mechanical latency of the system was slightly less than I msec; and maximal movement occurred $23 \mathrm{msec}$ after condenser-discharge. Owing to 
inertia of the system it is not possible to cite a value for true latency of the cell. However, the shortest interval measured from the beginning of mechanical stimulation (viz. Io msec) shows that latency following mechanical stimulation may be of the same order of magnitude as that following electrical stimulation (viz. $9 \mathrm{msec}$ ).

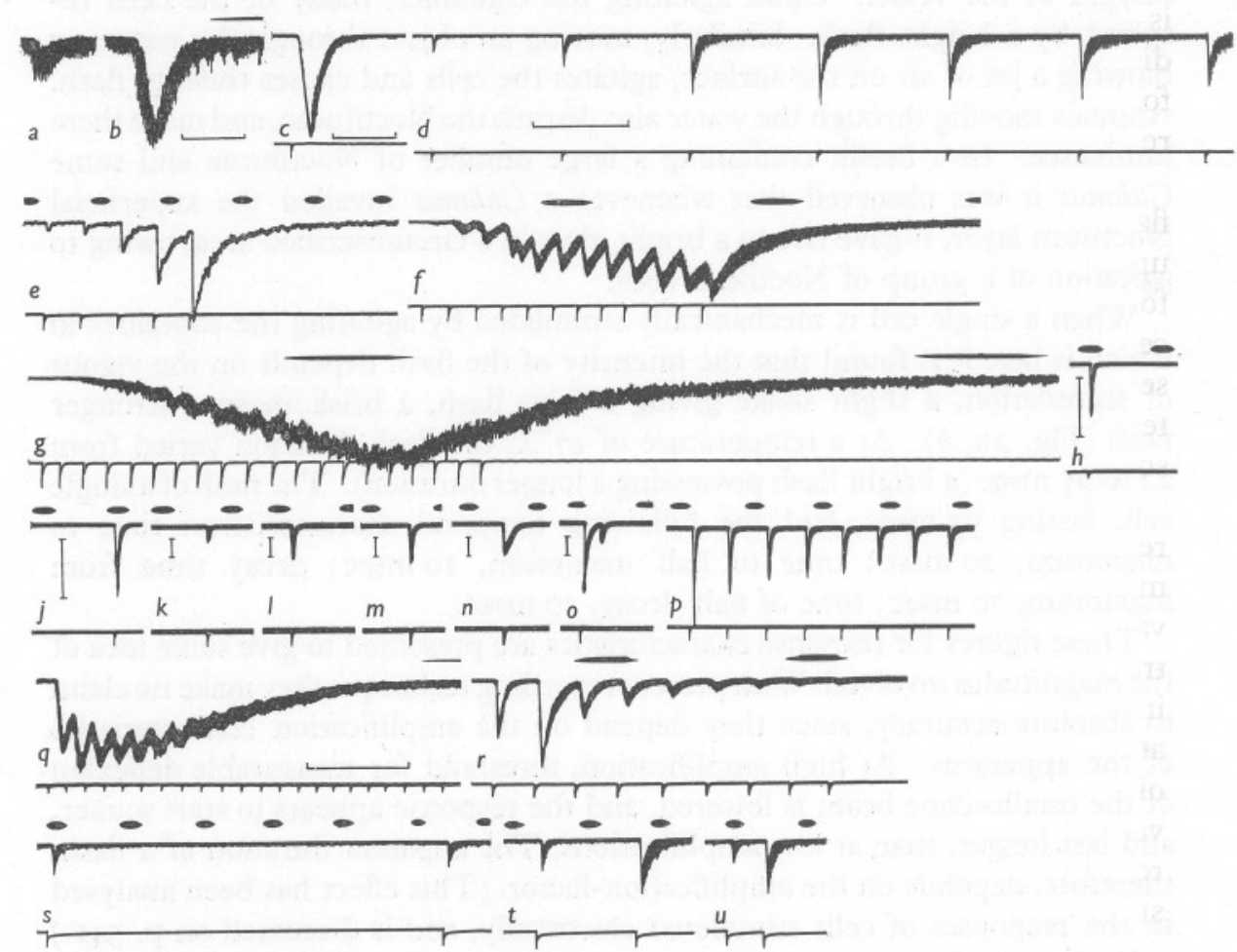

Fig. 2. Oscilloscope records of the flashes of a single Noctiluca cell. Photographs on moving paper of vertical excursions of the oscilloscope beams. $a, b$, flashes of a Noctiluca cell in response to mechanical stimulation (agitation of the container). $a$, strong; $b$, weak stimulus. The response is registered as a downward deflexion of the trace and is superposed on background noise. Time scale, Io msec. Temp. $17^{\circ} \mathrm{C}$. $c$, response of a Noctiluca cell to a single electrical shock. Time scale, ro msec. Temp. $19^{\circ}$ C. $d-g$, electrical stimulation of a Noctiluca cell at various frequencies. $d$, burst of shocks at $48 / \mathrm{min}$. Time scale, I sec. Temp. $2 \mathrm{I}^{\circ}$ C. $e$, burst of 5 shocks at $2 / \sec$ (background noise reduced with a low band-pass filter). $f$, burst of $\mathrm{I} 2$ shocks at $9 / \mathrm{sec}$. $g$, burst of 20 shocks at $28 / \mathrm{sec}$; fusion of individual responses almost complete, long after-glow. Temp. $e, f, g, 20^{\circ} \mathrm{C}$. $h-o$, effect of increasing strength of stimulus on intensity and characteristics of the responses. $h-n$, responses of the same cell to pulses of increasing duration (shocks from $0.023,0.5,0.72, \mathrm{I}, \mathrm{I} \cdot 95$, and $4 \mu \mathrm{F}$ condensers, respectively). Relative amplification shown to the left of each record. Note lengthening of the pulse in record $n$. 0 , double flash induced by a pulse at voltage $3 \times$ threshold. Temp. $19^{\circ}$ C. $p, q, r$, different patterns of responses under repetitive electrical stimulation. $p$, intervals $0.5 \mathrm{sec}$; $q, 0.03 \mathrm{sec} ; r, 0.2 \mathrm{sec}$. Temp. $19^{\circ} \mathrm{C}$. $s-u$, electrical stimulation of a single Noctiluca cell. Paired shocks at intervals of $5.5, \mathrm{I} \cdot 4$ and $0.5 \mathrm{sec}$. Temp. $20.4^{\circ} \mathrm{C}$. Time scale $e-p, r-u, \mathrm{I} / \mathrm{sec}$; $q, 0 . \mathrm{I}$ sec. Electrical stimuli shown on lower lines of records $c-u$. 
It may be noted that it proved impossible to make satisfactory observations on Noctiluca at sea when the ship was under way. The vibration of the vessel produced continuous excitation, and fatigued the luminescent response.

\section{Fatigue}

As others have observed before (e.g. Gosse, 1853), the flashing of Noctiluca is subject to fatigue. When one or a few Noctilucae are placed in a small dish and the dish is repeatedly shaken the cells flash several times, but after four or five flashes the light becomes weaker and disappears. Following a rest period of several minutes the cells recover and flash brightly once more.

Similar fatigue is shown under repetitive electrical stimulation, when the flashes decline in intensity, either initially from the first flash, or subsequent upon build-up to a plateau level (cf. histograms in Figs. 3 and 4). The time for recovery of full strength of response was determined by stimulating a cell at various intervals. The procedure was to give a pair of stimuli at some selected interval, and then to allow a rest period of 5-10 min before administering another pair of stimuli. The rest period of 5-10 min was chosen after some preliminary trials had shown that recovery occurred in that time.

With electrical stimulation it was found that recovery of full flash-intensity required an interval of about $2 \mathrm{~min}\left(19^{\circ} \mathrm{C}\right)$. Data obtained from one experiment in which a single cell was stimulated with pairs of shocks at given intervals are plotted in Fig. 5. Despite the scatter of observations, a general trend towards recovery of full luminescent intensity with lengthening of interval is apparent. The distribution of points representing flash-intensity at the $5 \mathrm{~min}$ level also gives some idea of the variation of response-intensity of a rested cell under electrical stimulation. It is uncertain whether this variability is intrinsic, or whether it is due to variation in apparent threshold resulting from small movements of the Noctiluca in the central well of the stimulating-chamber.

\section{ELECTRICAL STIMULATION}

A single electrical shock, above threshold-strength, elicits a flash of light from the cell or cells in the current-field (Fig. 2c). To bursts of shocks, a cell flashes repetitively, one flash per stimulus (Fig. $2 d-f$ ). With fast stimulation $(>3 / \mathrm{sec})$, some fusion of consecutive responses occurs, the effect becoming more pronounced as the frequency is raised (Fig. 2e-g). Fusion is nearly complete at a frequency of $28 / \mathrm{sec}$ (interval of $36 \mathrm{msec}$ ). This interval slightly exceeds the time required to reach maximal response-intensity, viz. $26 \mathrm{msec}$ (latent period + rise time). Following bursts of high-frequency stimulation, there is usually a prolonged after-glow, lasting as long as $\frac{3}{4} \sec$ (Fig. $2 g$ ).

\section{Temporal characteristics}

Single flashes, induced by electrical stimulation of resting cells, vary in duration from 69 to $830 \mathrm{msec}$. A flash lasting $145 \mathrm{msec}$ has the following 
temporal characteristics: rise time, $\mathrm{I} 7 \mathrm{msec}$; time to $\frac{1}{2}$ maximum, $8 \mathrm{msec}$; time of $\frac{1}{2}$ decay, $12 \mathrm{msec}$. Latent period, measured in records at maximal amplification, is $9 \mathrm{msec}$ (temp. $19^{\circ} \mathrm{C}$ ). Apart from latent period, these values agree reasonably well with those of responses evoked by mechanical

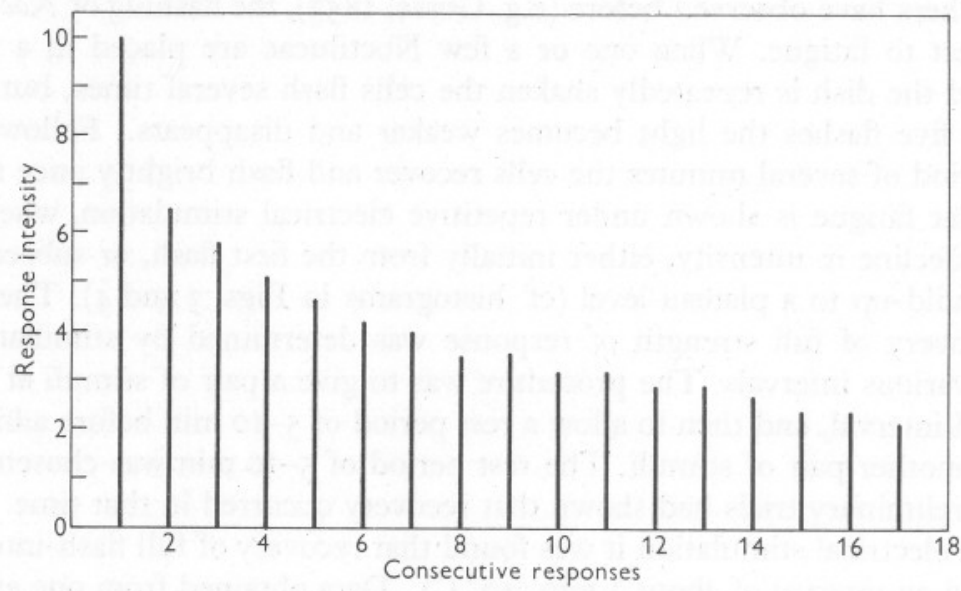

Fig. 3. Fatigue of photogeny in a Noctiluca cell. The cell was stimulated with a burst of 17 electric shocks at a frequency of $2 / \mathrm{sec}$. Note progressive decline in height of responses. Ordinates, luminescent intensities in arbitrary units. Temp. $19^{\circ} \mathrm{C}$.

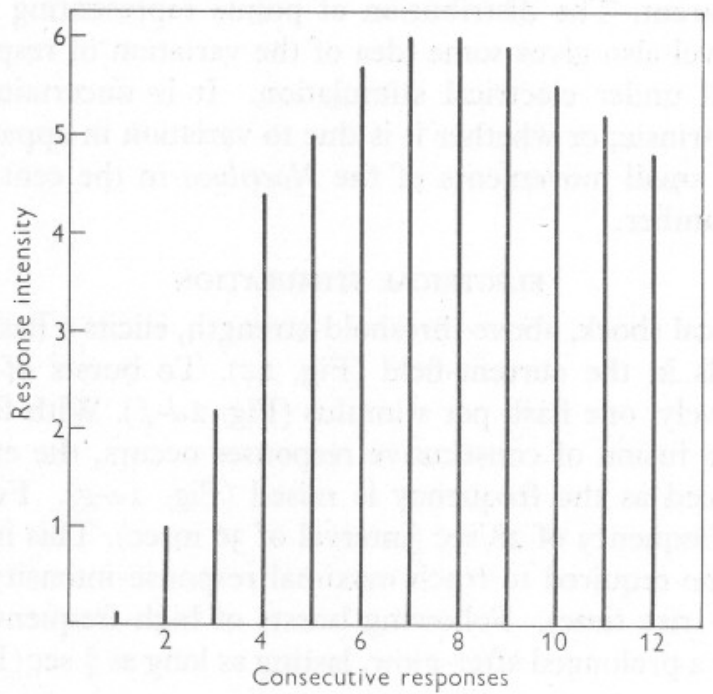

Fig. 4. Histogram showing facilitation and fatigue of consecutive responses in Noctiluca. A cell was stimulated with a series of 12 shocks at a frequency of $9 / \mathrm{sec}$. Each vertical line represents the intensity of a flash measured from the level of luminescence (if any) existing at the beginning of that response. Intensities (ordinates) in arbitrary units. Temp. $20^{\circ} \mathrm{C}$. 
stimulation (p. 537). The latency after mechanical stimulation is discussed on p. 538 .

The apparent duration of the flash as measured in the photographic records is influenced by the amplification of the apparatus. To determine the magnitude of this effect, flashes of a single cell were recorded at various amplifications and at fast paper speed. Since amplification of the apparatus varied in a linear manner, the responses at high amplification passed off the paper, and

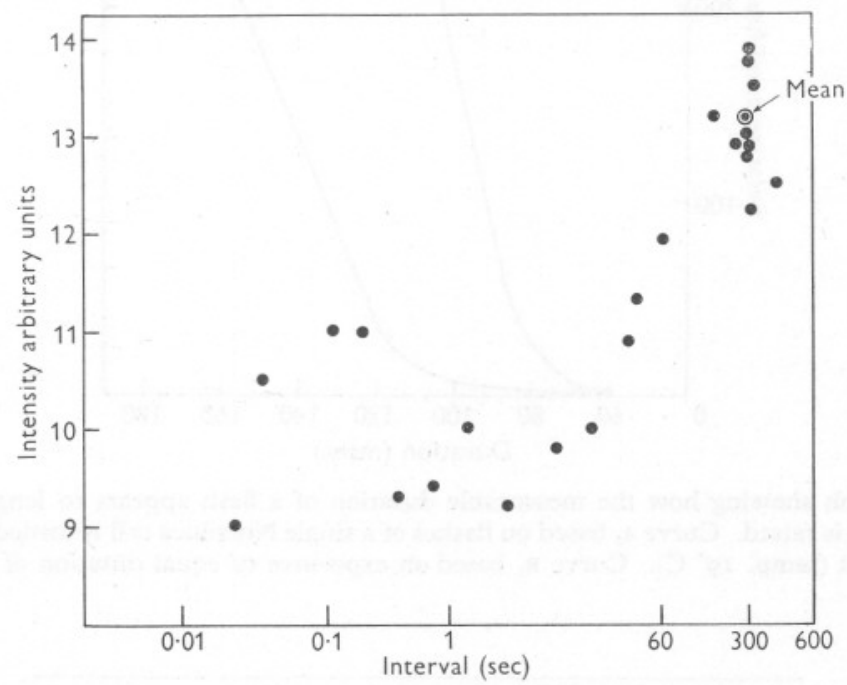

Fig. 5. Recovery of luminescence in a Noctiluca cell following electrical stimulation. Each point represents the intensity of a flash after a rest-period of selected duration since the last flash. Ordinates, intensities of response in arbitrary units. Abscissae, intervals in sec between 2 shocks ( $\log _{10}$ scale). Temp. $194^{\circ} \mathrm{C}$.

it was possible only to measure latent period and total duration of these responses. In order to secure a series of responses of approximately the same intensity, a rest period of $2 \mathrm{~min}$ was allowed between each flash, and conditions of stimulation were kept constant. The amplification factor was varied from 0.3 to 100 .

The results are plotted in Fig. $6 \mathrm{~A}$, in which it appears that the measurable duration of a flash is a high function of the amplification used. In the same figure there is a curve (B) showing apparent increase in duration of a brief flash from an artificial light source: actual exposures (flashes) had the same length (regulated by a mechanical device). When the amplification is increased by a factor of 100 , the response-duration appears to be lengthened two-fold. The maximal response-duration in this series of records was $\mathrm{I} 82 \mathrm{msec}\left(\mathrm{I} 9^{\circ} \mathrm{C}\right)$. The response-duration of $\mathrm{I} 45 \mathrm{msec}$, mentioned on p. 539, was determined with an amplification-factor of 3 . At maximal amplification of I00, this would appear $80 \mathrm{msec}$ longer (i.e. $225 \mathrm{msec}$ ). 


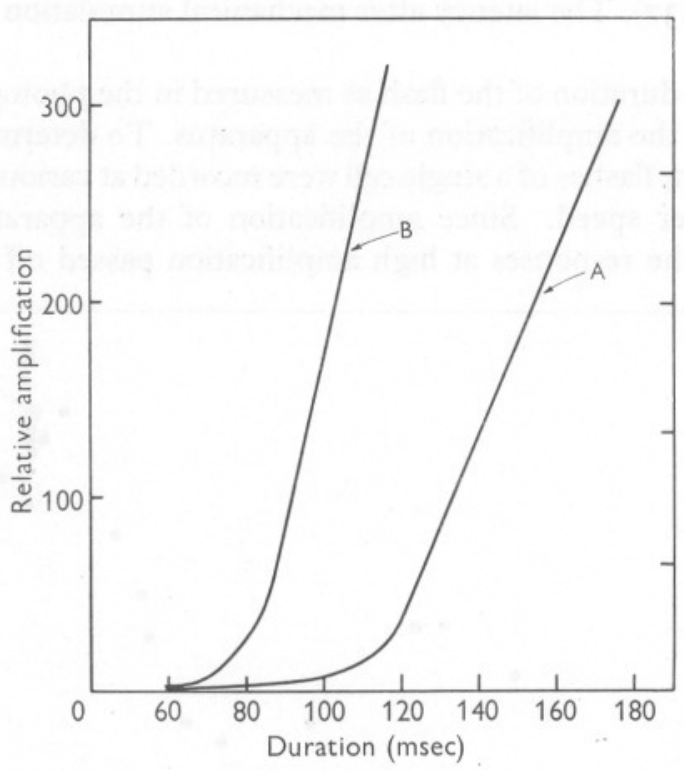

Fig. 6. Graph showing how the measurable duration of a flash appears to lengthen as the amplification is raised. Curve A, based on flashes of a single Noctiluca cell recorded at different amplifications (temp. I9 ${ }^{\circ} \mathrm{C}$ ). Curve B, based on exposures of equal duration of an artificial light source.

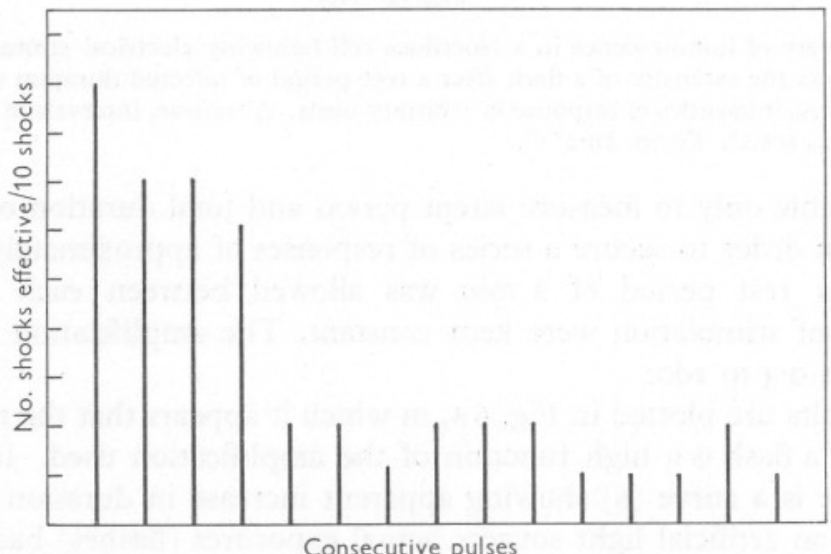

Fig. 7. Fluctuation of threshold. A Noctiluca cell was stimulated with a burst of 150 electrical pulses at a frequency of $3 / \mathrm{sec}$. On the ordinates are plotted the number of stimuli effective in each consecutive series of ro shocks (total scale $=10$ ). With continued stimulation, fewer pulses were effective, until only each 4 th or $5^{\text {th }}$ shock produced a flash. Temp. $19^{\circ} \mathrm{C}$. 


\section{Effect of increasing stimulus-strength}

The intensity of a flash produced by Noctiluca depends on the strength of stimulus. This was determined either by varying the voltage, or by switching to different stimulating capacitors. When the current was gradually increased above threshold level, it was found that the response increased correspondingly (Fig. $2 h-n$ ). By doubling the stimulating voltage, the intensity of the luminescent flash was increased fivefold. A plateau-level of response was finally reached, above which further increment of stimulus-strength produced no further increase in flash-intensity.

At maximal stimulus-intensities the flashes were usually prolonged in duration as well as increased in intensity (Fig. $2 n$ ). Strong flashes, several times threshold-strength, sometimes gave rise to double flashes in quick succession (Fig. 20). Continued stimulation at high voltages produced depression of the response, and finally extinction. The effect was irreversible, and indicative of cellular injury.

After a prolonged period of electrical stimulation it was usually found that the threshold was raised. This was also exhibited by giving a series of shocks at threshold-strength. During such a series occasional shocks became ineffective (Fig. 7). No evidence was found for summation of subthreshold stimuli: bursts of subthreshold shocks at various frequencies failed to elicit a response.

\section{Facilitation}

Noctiluca cells often but not invariably show facilitation under electrical stimulation. This is a phenomenon in which each stimulus engenders a persistent excitatory state which, when added to that produced by the next stimulus, augments the intensity of the next response. Under repetitive stimulation the successive flashes of a Noctiluca cell sometimes increase in intensity (Fig. 4).

Facilitatory increment occurred at intervals up to $\mathrm{I} \cdot 4 \mathrm{sec}$, too long to allow fusion of separate responses, and increased at shorter intervals (Fig. $2 d, e, f$, $s, t, u)$. During a long burst of stimuli, facilitation was evident initially for the first eight or so responses, whereupon the responses reached plateau level, which was briefly maintained and followed by a decline of response-intensity (Fig. 4). It has already been noted that the luminescent responses of Noctiluca are fatigued by repetitive stimulation at short intervals, recovery requiring some $2 \mathrm{~min}$. This recovery period, during which the flash-intensity is depressed below normal, far exceeds the maximal interval at which facilitation is operative (viz. ca. $\mathrm{I} \cdot 5 \mathrm{sec}$ ).

It is concluded, therefore, that facilitatory increment is partly masked by fatigue, i.e. the height of each facilitated response is the resultant of two conflicting factors, increment of excitation and temporary depression of the photogenic system. 
In some other instances, facilitation was shown only in the second of a series of flashes, the third and subsequent flashes progressively decreasing in intensity (Fig. 2q,r). Again, there were many records in which the first flash of a series was maximal, and the subsequent flashes diminished in intensity (Figs. 2p, 3). This progressive diminution of successive flashes has been alluded to previously as fatigue (p. 539). I was unable to discover any apparent reason for this variability in the responses of different cells. The existence of facilitation in many cells, however, was well established, and is of intrinsic interest.

\section{Illumination without effect}

Exposure to light is said to cause inhibition of luminescence in Noctiluca (Henneguy, I888) as well as certain other species (dinoflagellate Gonyaulax and ctenophores) (Harvey, I952; Haxo \& Sweeney, I955). In view of the reported sensitivity of Noctiluca to light, it was decided to re-investigate the phenomenon. The procedure was as follows. A single Noctiluca cell or a group of cells was maintained in the dark for an hour, and then stimulated with an electrical shock to record the level of a normal response. The cell or cells were then exposed to a daylight tungsten bulb for Io-30 min at illumination levels up to $c a$. I kilolux. After extinguishing the light the Noctilucae were again stimulated electrically. The responses recorded were no weaker than those elicited before illumination. This result agrees with the observations of E. N. Harvey (I926) who found that daylight was without effect in suppressing the luminescence of Noctiluca. Massart (1893) reported a diurnal rhythm of luminescence in Noctiluca in continual darkness. I did not observe that the cells which I studied gave any brighter flashes by night than by day.

\section{SPECTRAL COMPOSITION OF THE LIGHT}

Dense layers of Noctiluca were obtained from plankton hauls, and the light produced by mechanical agitation of these samples was sufficiently bright and persistent for determination of its spectral composition. As an initial attempt, I examined the light of Noctiluca visually through a series of glass and gelatine filters (Chance, Ilford and Kodak), so as to judge the efficiency of the recording system. Filters used were purple (transmitting in the blue and red), green, yellow, orange, and red. The light of Noctiluca was largely eliminated by red and orange filters (transmitting above $590 \mathrm{~m} \mu$ ), faintly visible through blue and green filters (transmitting in the range 400$6 \operatorname{Io} \mathrm{m} \mu$ ). From these observations it appears that the light of Noctiluca has a spectral distribution between about $400-600 \mathrm{~m} \mu$. This range is in the spectral region to which the photomultiplier is most sensitive.

Relative spectral emission was determined quantitatively, as follows. The light from Noctilucae was passed through coloured spectral filters, and the 
resultant electrical responses were estimated by measuring oscilloscope deflexions. The spectral filters were mounted in openings about the margin of an opaque disc, which rotated beneath the photomultiplier. The speed of the disc was slightly faster than I rev./sec. Light was produced by discharging a suspension of Noctilucae from a pipette into a vessel lying below the disc. The experimental arrangement is depicted diagrammatically in another paper (Nicol, I957c, fig. I), where the method is described in more detail.

Two discs were used, each containing 8 or 9 different kinds of spectral filters. These are tabulated in another paper (Nicol, I958c).

The filters were slightly wider than the diameter of the photomultiplier end-window. An opaque blank space between two contiguous filters allowed the responses of the individual filters to be distinguished; and a double blank at one place on the disc permitted a complete rotation to be determined, and the many responses during that rotation to be related to the corresponding filters on the disc. A sample record is shown in Fig. 8.

The flash produced by squirting a suspension of Noctilucae lasted about 3-4 sec, and during that time it changed greatly in intensity, rising quickly to a maximum, and then decaying. In order to follow changes in absolute intensity, identical filters, termed reference filters, were placed between each of the other spectral filters. The reference filters were Ilford blue-green 603 or Ilford green 604 . The value for the measured response of each of the spectral filters was then altered, relative to the responses of the two contiguous reference filters.

Values for relative spectral energy were calculated from the photographic records. The method is described in detail in other papers (Nicol, I957b, $c, 1958 b$ ).

A curve for relative spectral emission is shown in Fig. 9. The light is blue: emission extends from about $420-580 \mathrm{~m} \mu$, with a maximum at $470 \mathrm{~m} \mu$. The curve is unimodal, and resembles that of luminous extracts of the dinoflagellate Gonyaulax polyedra (Hastings \& Sweeney, I957). Several other pelagic animals emit blue light of somewhat similar spectral composition (Kampa \& Boden, I957; Nicol, I958c). It may be that a curve of this kind is fairly representative of the luminescence of many marine organisms. Ctenophores, with green light, are obvious exceptions.

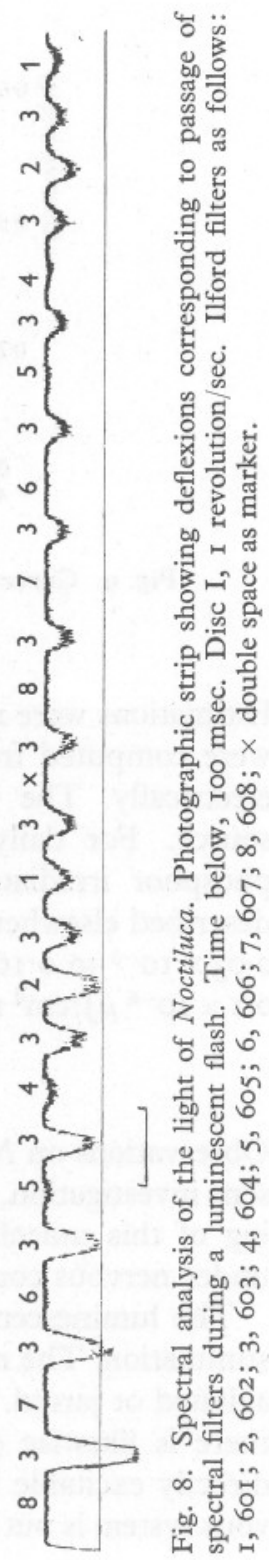




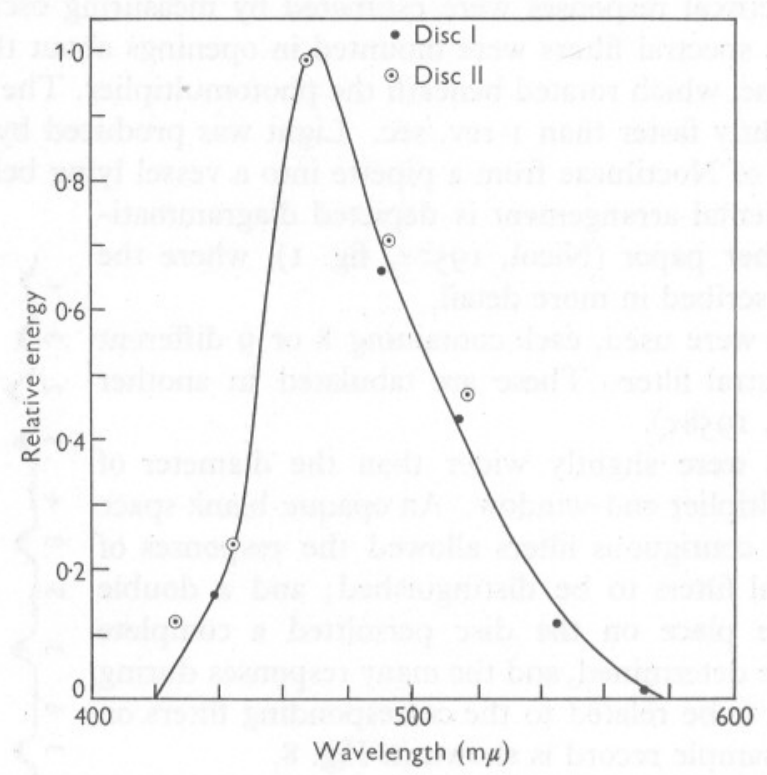

Fig. 9. Curve showing relative spectral composition of the light of Noctiluca.

\section{INTENSITY OF FLASH}

Estimations were made of the intensity of light in a flash of Noctiluca. These were computed from oscilloscope records of flashes of a single cell, excited electrically. The whole system was calibrated against a substandard light source. For daily use, a photometric standard consisting of a stilbene phosphor irradiated by ${ }^{60} \mathrm{Co}$ was used. Calibration and calculations are described elsewhere (Nicol, 1958a). Radiant flux in a single flash varied from $0.03 \times \mathrm{IO}^{-6}$ to $0 . \mathrm{I} 6 \times \mathrm{IO}^{-6} \mu \mathrm{J} / \mathrm{cm}^{2}$ receptor surface at $\mathrm{I} \mathrm{cm}$. Mean flux was $0 \cdot \mathrm{I} \times \mathrm{IO}^{-6} \mu \mathrm{J} / \mathrm{cm}^{2}$ receptor surface at I $\mathrm{cm}\left(23^{\circ} \mathrm{C}\right)$.

\section{DISCUSSION}

Observations on Noctiluca by E. B. Harvey (I9I7), and by myself in the present investigation, have revealed many points of similarity between the flashing of this unicellular organism, and of metazoans where luminescence is under nervous control.

The luminescence of Noctiluca is intracellular, and is evoked by external stimulation. The natural stimulus is mechanical, Noctiluca flashing when it is agitated or jarred. But flashing is also produced by electrical stimulation and there is likewise evidence that the photocytes of some higher animals are directly excitable by electrical pulses, e.g. those of polynoids when the nervous system is put out of action by anaesthesia (Nicol, I957a). The luminescent 
systems of these animals can thus be added to the list of effectors which are directly excitable by electrical stimuli, viz. muscle, exocrine glands, flagella, and electrical tissue.

The flash of Noctiluca is very brief, usually about $100 \mathrm{msec}$ following mechanical stimulation, but showing considerable variation. Some comparable data for the intracellular flashes of other animals, recorded from point sources of photogenic tissue, are assembled in Table I. Of equal brevity are the flashes of Gonyaulax and of single scales of polynoids; in contrast is the prolonged glow of Pyrosoma, $7 \mathrm{sec}$ or more in duration. The brief latency (about $10 \mathrm{msec}$ ) is comparable to that found in luminescent flashes of some metazoans, e.g. untreated and anaesthetized scales of polynoids, where the response is normally under nervous control.

TABLE 1. DURATION OF INTRACELLULAR FLASHES OF SOME MARINE ANIMALS

(Recordings from point sources.)

\begin{tabular}{|c|c|c|c|}
\hline Animal & Duration & Temp. ${ }^{\circ} \mathrm{C}$ & Reference \\
\hline Gonyaulax polyedra & I $30 \mathrm{msec}$ & 一 & Hastings \& Sweeney, I957 \\
\hline Noctiluca miliaris & 22-95 msec & I7 & Original \\
\hline Aequorea forskalea & $0.2-0.4 \mathrm{sec}$ & $14-16$ & Davenport \& Nicol, r955 \\
\hline Renilla köllikeri & $0.25-\mathrm{I} \mathrm{sec}$ & $17-20$ & Nicol, I955 \\
\hline Beroë ovata & $0.16 \mathrm{sec}$ & $20-21$ & Nicol, I958c \\
\hline Mnemiopsis leidyi & $0.290 \mathrm{sec}$ & $2 \mathrm{I}-23.5$ & Chang, I954 \\
\hline Acholoë astericola & $63-103 \mathrm{msec}$ & $18-20$ & Nicol, I953 \\
\hline Pyrosoma atlanticum & $7 \mathrm{sec}$ & 25 & Nicol, I958c \\
\hline
\end{tabular}

Under repetitive electrical stimulation, the flashes of Noctiluca show summation, fusion and facilitation, as do those of various higher forms, e.g. hydromedusae, sea pens, ctenophores and polynoids (Nicol, 1953; Chang, 1954; Davenport \& Nicol, 1955). There has been some question whether the facilitatory process takes place within the photogenic cell, or in the nervous system, or whether it operates at the neurophotocyte boundary. The observations on Noctiluca show that facilitation can occur within the confines of a single photogenic cell. It has also been demonstrated to occur in anaesthetized elytra of polynoids, when the nerve-fibres are non-operative; in this instance, also, one must postulate a facilitatory process within the photocyte (Nicol, I957a). Still to be resolved is the intracellular level at which facilitation operates, whether it involves the initial stages of excitation, or some later stages of the biochemical reactions producing the light.

The emission spectrum of Noctiluca light extends from about 420 to $580 \mathrm{~m} \mu$, with a peak at about $470 \mathrm{~m} \mu$. Clear oceanic water is most transparent to blue light of this composition, and it is in this region of the spectrum that the eyes of some deep-sea species are most sensitive, viz. squid and teleosts $\left(\lambda_{\text {max. }} 493\right.$ and $480 \mathrm{~m} \mu$, respectively) (Denton \& Warren, 1957; Hubbard \& St George, 1958).

The radiant flux in a flash of a Noctiluca ranges from $0.03 \times 10^{-6}$ to 
$0.16 \times \mathrm{IO}^{-6} \mu \mathrm{J} / \mathrm{cm}^{2}$ receptor surface at $\mathrm{I} \mathrm{cm}$. On the assumption that the cell emits uniformly in all directions, the total energy irradiated from a Noctiluca is $0.38 \times 10^{-6}$ to $2.0 \mathrm{I} \times \mathrm{IO}^{-6} \mu \mathrm{J} / 4 \pi$ sterads. Values for radiant flux are available for two other protozoans, viz. the radiolarians Cytocladus and Aulosphaera which emit $0.6 \times 10^{-5}$ to $5.3 \times 10^{-5} \mu \mathrm{W} / \mathrm{cm}^{2}$ receptor surface at $\mathrm{I} \mathrm{cm}$ (Nicol, I958c). Nichols (1924) has estimated the brightness of individual flashes of dinoflagellates at 0.1 I6 mlam. When allowance is made for the blue composition of dinoflagellate light, this brightness estimate is equivalent, approximately, to a radiant flux of $0.354 \times 10^{-5} \mu \mathrm{W} / \mathrm{cm}^{2}$ receptor surface at I $\mathrm{cm}$ distance. Since the individual flashes of dinoflagellates are only some $0 . \mathrm{I} \mathrm{sec}$ in duration, equivalent flux in Nichols's estimates, averaged over I sec, is of the order of $0.15 \times 10^{-6} \mu \mathrm{J} / \mathrm{cm}^{2}$ receptor surface at $\mathrm{I} \mathrm{cm}$ distance. This shows reasonably good agreement with the present estimates of radiant flux of Noctiluca.

I am indebted to Dr M. Parke for undertaking the culture of Noctiluca, and to Mr E. I. Butler for technical assistance. Mr G. N. Harding of the U.K. Atomic Energy Authority supplied the ${ }^{60} \mathrm{Co}$-stilbene phosphor, for which I am grateful. Part of the apparatus used in this research was purchased with grants from the Royal Society.

\section{SUMMARY}

The luminescent flashes of Noctiluca miliaris have been recorded by means of a blue-sensitive photomultiplier. Following mechanical stimulation, a cell gives a brief flash, lasting up to $90 \mathrm{msec}$. Repeated stimulation quickly leads to fatigue of photogeny; rest allows recovery. With electrical stimulation there is a flash for each pulse. With repetitive electrical stimulation, there is summation, then fusion of flashes, depending on the frequency. Some cells gave clear evidence of facilitation. Increasing the current produced brighter flashes. Illumination was without effect on the photogenic response.

The relative spectral composition of the light was determined by means of glass and gelatine filters. Emission extends from about 420 to $580 \mathrm{~m} \mu$, with a maximum at about $470 \mathrm{~m} \mu$. Radiant flux in a flash from a single cell ranges from $0.03 \times 10^{-6}$ to $0.16 \times 10^{-6} \mu \mathrm{J} / \mathrm{cm}^{2}$ receptor surface at $\mathrm{I} \mathrm{cm}$ distance $\left(23^{\circ} \mathrm{C}\right)$.

\section{REFERENCES}

Chang, J. J., 1954. Analysis of the luminescent response of the ctenophore, Mnemiopsis leidyi to stimulation. F. cell. comp. Physiol., Vol. 44, pp. 365-94.

DAvenPorT, D. \& Nicol, J. A. C., I955. Luminescence in Hydromedusae. Proc. roy. Soc. B, Vol. I44, pp. 399-4I2.

Davis, C. C., I953. Concerning the flotation mechanism of Noctiluca. Ecology, Vol.34, pp. $189-92$.

Denton, E. J. \& WARren, F. J., 1957. The photosensitive pigments in the retinae of deep-sea fish. F. mar. biol. Ass. U.K., Vol. 36, pp. 65I-62. 
Gosse, P. H., 1853. A Naturalist's Rambles on the Devonshire Coast. London: John van Voorst.

HARVEY, E. B., I9I7. A physiological study of specific gravity and of luminescence in Noctiluca, with special reference to anaesthesia. Publ. Carneg. Instn, No. 25I, pp. $235-53$.

HARveY, E. N., 1926. On the inhibition of animal luminescence by light. Biol. Bull., Woods Hole, Vol. 51, pp. 85-8.

1952. Bioluminescence. New York: Academic Press.

HAstings, J. W. \& SWEENEY, B. M., 1957. The luminescent reaction in extracts of the marine dinoflagellate, Gonyaulax polyedra. f. cell. comp. Physiol., Vol. 49, pp. 209-26.

HAxo, F. T. \& SweEney, B. M., 1955. Bioluminescence in Gonyaulax polyedra. In The Luminescence of Biological Systems, ed. F. H. Johnson, pp. 415-20. Washington: Amer. Ass. Adv. Sci.

HenNeguY, L. F., I888. Influence de la lumière sur la phosphorescence des Noctiluques. C.R. Soc. Biol., Paris, T. 5, pp. 707-8.

Hubbard, R. \& St George, R. C. C., I958. The rhodopsin system of the squid. $\mathcal{F}$. gen. Physiol., Vol. 4I, pp. 50I-28.

KAMPA, E. M. \& BoDEN, B. P., I957. Light generation in a sonic-scattering layer. Deep-sea Res., Vol. 4, pp. 73-92.

Massart, J., I893. Sur l'irritabilité des Noctiliques. Bull. sci. Fr. Belg., T. 25, pp. 5976.

Nichols, E. L., I924. The brightness of marine luminescence. Science, Vol. 60, pp. 592-3.

NicoL, J. A. C., 1953. Luminescence in polynoid worms. F. mar. biol. Ass. U.K., Vol. 32, pp. 65-86.

- 1955. Nervous regulation of luminescence in the sea pansy Renilla köllikeri. f. exp. Biol., Vol. 32, pp. 619-35.

- 1957a. Luminescence in polynoids. II. Different modes of response in the elytra. F. mar. biol. Ass. U.K., Vol. 36, pp. 26I-9.

- I957b. Spectral composition of the light of polynoid worms. F. mar. biol. Ass. U.K., Vol. 36, pp. 529-38.

- I957c. Spectral composition of the light of Chaetopterus. F. mar. biol. Ass. U.K., Vol. 36, pp. 629-42.

- 1958a. Luminescence in polynoids. IV. Measurements of light intensity. F. mar. biol. Ass. U.K., Vol. 37, pp. 33-4I.

1958b. Spectral composition of the light of Pholas dactylus L. F. mar. biol. Ass. U.K., Vol. 37, pp. 43-7.

- 1958c. Observations on luminescence in pelagic animals. F. mar. biol. Ass. U.K., Vol. 37, pp. 705-52. 